AC 2011-1645: LIVING-LEARNING COMMUNITIES AS A POTENTIAL INTERVENTION TO INCREASE THE RETENTION OF FIRST-YEAR ENGINEERS

Justin P. Micomonaco, Michigan State University 


\section{Living-Learning Communities as an Intervention to Increase the Retention of First-Year Engineers}

\section{Background}

The challenge to produce both a greater quantity and higher quality of engineers in the United States is well-documented. ${ }^{1,2}$ There have been considerable efforts to recruit additional students to engineering, yielding modest results; however, the increase in enrollment has not coincided with an increase in engineering graduates. ${ }^{3,4}$ Therefore the departure of students from the discipline remains an issue.

The primary focus in engineering education as well as other STEM fields has been to improve the curriculum and pedagogy of faculty. STEM educators adopted this focus largely in response to Seymour and Hewitt's seminal work studying students who depart from the STEM disciplines. Noting that leavers do not differ significantly in terms of academic achievement or preparedness, their findings indicate that students leave the STEM disciplines primarily due to the content-laden curriculum, the inadequate and uninteresting instruction, and an overall disinterest in STEM careers. ${ }^{5}$ As a result, engineering has invested significantly in reforming their educational efforts through curricular reform and pedagogical innovations. ${ }^{6,7}$

One intervention used more generally in higher education to address issues of student retention, engagement and learning outcomes is the living-learning community (LLC). LLCs enable institutions to embed a smaller, more intimate learning environment for students within their larger academic enterprise. ${ }^{8,9}$ In general, LLCs are recognized as promoting a number of outcomes linked to student success including increased engagement and connection to faculty. ${ }^{10}$, ${ }^{11,12}$ Despite this research, LLCs are used infrequently in the discipline of engineering to support students. As a result, there is a lack of research on the effectiveness of LLCs to promote both retention within the discipline and student learning.

This paper outlines preliminary findings from a larger study of the use LLCs in engineering. In this paper, I report on the pre-college characteristics of engineering students who chose to participate in a LLC as compared to students who chose not to participate. In addition, I compare these two groups (participants and non-participants in the LLC) in terms of their persistence-related attitudes and behaviors at the end of the academic year including disciplinary persistence data as of the start of the sophomore year. Finally I provide a preliminary analysis of the relationships between these attitudes and behaviors, and measures of persistence.

\section{Research Questions}

This paper will address the following research questions:

1. What are the pre-college characteristics of students who choose to participate in a LLC? How do they compare to non-participants?

2. What are the attitudes and behaviors of engineering students who choose to participate in a LLC at the end of the academic year? How do they compare to students not in a LLC? 
3. How do participants in a LLC compare with students not in a LLC in terms of measures of disciplinary persistence?

\section{Theoretical Framework}

Recently a relevant theoretical framework for studying disciplinary retention decisions among undergraduate engineers was proposed and subsequently revised. ${ }^{13,14}$ The model modifies Tinto's Interactionalist Theory of Student Departure that is often used when studying undergraduates who choose to drop out of college. ${ }^{15}$ In the model, pre-college characteristics (e.g., pre-college academic achievement, family support, etc.) significantly influence college departure decisions whether from the major or from college altogether. The pre-college characteristics act by affecting how students interpret their academic and social experiences ("student experience") and how they feel integrated or a sense of belonging. ${ }^{16}$ The level of academic and social integration links to student success and persistence.

The revisions to the general model of student persistence to a disciplinary retention model for engineering education have resulted in a few changes. First, the pre-college characteristics have been altered as additional characteristics related to persistence in engineering have been identified including (a) quantitative skills, (b) attitude about studying engineering, (c) commitment to engineering, and (d) study habits. ${ }^{17}$ Second, Veenstra et al. proposed three intermediary factors that affect a student's decision to remain in engineering: (a) academic success; (b) commitment to the college of engineering; and (c) commitment to learning the discipline of engineering. ${ }^{18}$ Third qualitative research examining Tinto's concepts of academic and social integration as it relates to disciplinary retention in engineering suggests a more integrated view of the student experience. As it pertains to engineering retention, the student experience is defined generally as the student's sense of belonging consisting of (a) connection to engineering including faculty, peers and the college of engineering; (b) commitment to engineering and (c) and socialization to engineering (see Figure 1 for full model). To study the relationship between participation in a LLC on disciplinary retention, I examine these intermediate components that impact retention as well as direct measures of retention.

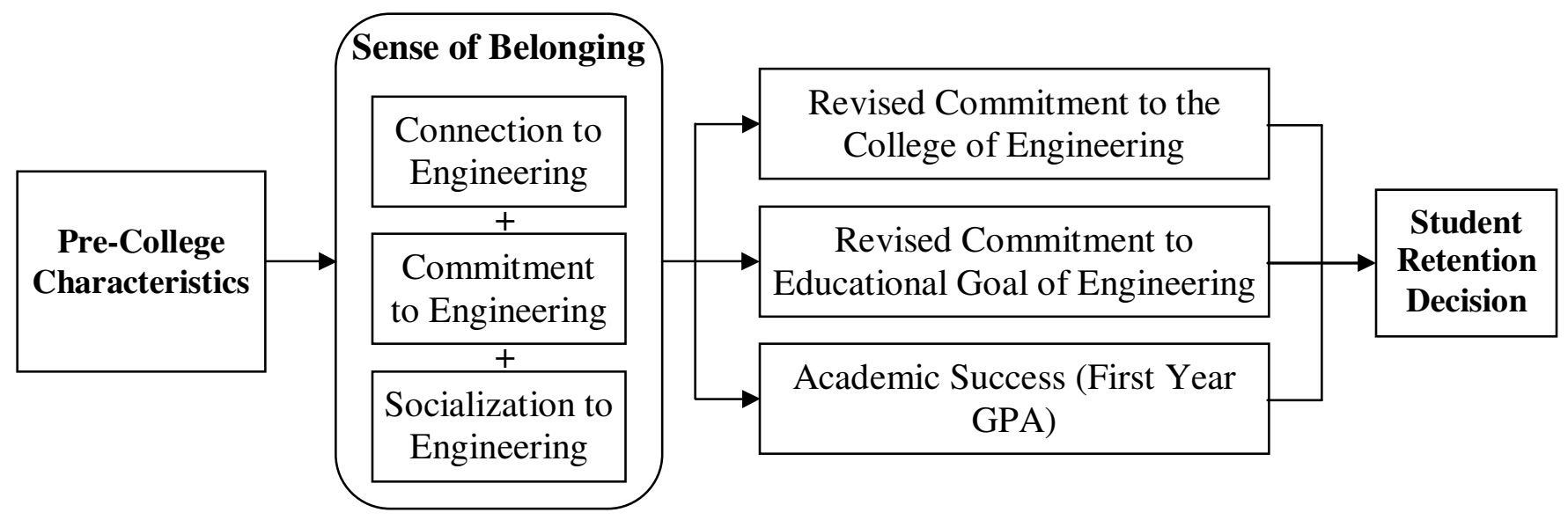

Figure 1: Revised Model of Engineering Student Retention 


\section{Sample}

The participants in this study were first-year pre-engineering students at a large, research university in the Midwest. At this institution, students who are pre-engineering have stated a preference to major in an engineering discipline, but must apply to the major after completing a series of required courses. Normally students apply to the College of Engineering in their sophomore year. First-year pre-engineering students at the institution enroll in a required introductory design sequence of two courses. Most often, students commence the sequence in the fall semester and complete the second course in the spring semester of their first year. The sample for this paper constitutes all first-year students who declared an intent to major in engineering or enrolled in the required introductory design sequence for Fall 2009 ( $N=499)$. All entering pre-engineering students have the option of participating in the institution's LLC for engineers. In that year, approximately $30 \%$ of students chose to live in the College of Engineering's LLC.

\section{Data Collection}

I collected the data three times during the 2009-10 academic year using the laboratory meetings of the first year introductory design sequence. The pre-test version of the instrument was administered during the second full week of classes (Time 0 ). The post-tests were administered at the beginning of the spring semester (Time 1) and at the end of the spring semester (Time 2). The data for this study were drawn from Time 0 and Time 2 only.

I asked students to complete the survey at the beginning of the scheduled laboratory meetings. The participants did not receive any incentive to participate in the survey. Using an online classroom platform, the survey required participants to login using their personal identification number (PIN) to participate. The PIN enabled responses to be tracked across the three administrations of the survey and to link responses to demographic data and pre-college characteristics.

By using class meetings to administer the survey, the data collection yielded high response rates. The percentage of students enrolled in these courses that responded to the survey was $85 \%$ at Time 0 and $81 \%$ at Time 2 based on enrollment figures for the individual course (i.e., number of first-year students enrolled in the courses surveyed). These responses represented $74 \%$ and $59 \%$ respectively of the entire sample $(\mathrm{N}=499)$ of first-year students targeted in this study. The difference in the reported response rates is due to differences in enrollment patterns caused by students taking courses out of sequence or departing the major during the academic year.

\section{Instrumentation}

For the study, I used quantitative methods to analyze a combination of existing precollege data and survey data. The data for this paper draws from items measuring students' (a) expectations related to college and studying engineering, and (b) attitudes and behaviors while in college and studying engineering. 
I developed the measures to examine students' expectations, attitudes and behaviors related to college and studying engineering using the Revised Model of Engineering Student Retention (see Figure 1). ${ }^{19,20}$ Identifying the factors that relate to persistence in engineering from these theoretical frameworks, I developed items to measure the following: (a) students' commitment to engineering; (b) students' connection to the engineering college; (c) students' connection to engineering faculty; and (d) students' connection to engineering peers. Participants indicated the extent to which they agreed with statements in each of these areas on a Likert scale with the following four options: (a) strongly agree; (b) somewhat agree; (c) somewhat disagree; and (d) strongly disagree.

This part of the survey was reviewed by experts to enhance validity. Three content experts who conduct research in engineering education reviewed the questions, providing feedback on individual items and the overall structure of the instrument. In addition, two researchers with experience in instrument design reviewed the paper and pencil version to provide structural feedback to improve flow. Finally, I piloted the survey using a group of students. Six engineering students completed the survey via pencil and paper and provided feedback regarding the clarity of survey items. Then the students were asked to reflect on their understanding of certain items to ensure clear wording where concerns were previously raised. The feedback from the pilot resulted in the rewording of some questions to clarify some of the agree/disagree statements.

From the data collected during the first survey administration, I used a combination of scale reliability tests and factor analysis to develop sub-scales in each of the theoretical areas. After exploring inter-item reliability and correlations, I decided to employ a principle-component analysis (PCA) for each of the four theoretical components listed above. I chose PCA because it is useful when trying to reduce the number of data items and when trying to see how survey items "hang together". 21

I employed an oblique rotation and examined the loadings for each theoretical component (i.e., commitment to engineering, connection to faculty, connection to peers, connection to college) specifying the number of items in a step-wise fashion starting with total survey items minus one (n-1) and ending with one factor. Then I reviewed the results of the PCA at each point. I made decisions about the number of factors to include based on a combination of the eigenvalues, the pattern and structure coefficients and the component correlation matrix. A brief summary of the components for each theoretical factor, the names of each component factor used in this study, and the variance explained are listed in Table 1.

Table 1: PCA of Theoretical Factors into Component Factors

\begin{tabular}{|c|c|c|c|c|}
\hline Theoretical Factor & Components & Eigenvalue & $\begin{array}{c}\text { Variance } \\
\text { Explained } \\
\end{array}$ & $\begin{array}{c}\text { Total } \\
\text { Variance } \\
\end{array}$ \\
\hline $\begin{array}{l}\text { Students' Commitment } \\
\text { to Engineering }\end{array}$ & $\begin{array}{l}\text { 1. Commitment to } \\
\text { Engineering }\end{array}$ & 2.499 & $62.48 \%$ & $62.48 \%$ \\
\hline $\begin{array}{l}\text { Students' Connection } \\
\text { to the Engineering } \\
\text { College }\end{array}$ & $\begin{array}{l}\text { 1. Supported by College } \\
\text { 2. Member of College }\end{array}$ & $\begin{array}{c}1.992 \\
.951\end{array}$ & $\begin{array}{l}39.85 \% \\
19.03 \%\end{array}$ & $58.87 \%$ \\
\hline
\end{tabular}




\begin{tabular}{lllll}
$\begin{array}{l}\text { Students' Connection } \\
\text { to Engineering Faculty }\end{array}$ & $\begin{array}{l}\text { 1. Student Interactions with } \\
\text { Faculty }\end{array}$ & 2.354 & $47.08 \%$ & $71.80 \%$ \\
& $\begin{array}{l}\text { 2. Student Perception of } \\
\text { Faculty }\end{array}$ & 1.236 & $24.72 \%$ & \\
$\begin{array}{l}\text { Students' Connection } \\
\text { to Engineering Peers }\end{array}$ & $\begin{array}{l}\text { 1. Study Habits with } \\
\text { Engineering Peers }\end{array}$ & 3.138 & $39.23 \%$ & $71.42 \%$ \\
$\begin{array}{l}\text { 2. Relationships with } \\
\text { Engineering Peers }\end{array}$ & 1.422 & $17.78 \%$ & \\
& $\begin{array}{l}\text { 3. Comfortable Seeking } \\
\text { Help from Engineering } \\
\text { Peers }\end{array}$ & 1.153 & $14.41 \%$ & \\
\hline
\end{tabular}

Examples of the types of Likert statements included in each component factor by the PCA are listed in Table 2. Participants indicated the extent to which they agreed with each statement.

Table 2: Survey Question Examples Mapped to Component Factor

\begin{tabular}{ll}
\hline Component Factor & Example Likert Statements \\
\hline $\begin{array}{l}\text { Commitment to Engineering } \\
\text { Supported by College }\end{array}$ & $\begin{array}{l}\text { I am confident that engineering is the correct major for me. } \\
\text { I feel supported by the College of Engineering. } \\
\text { There are many resources (e.g., advising, career services) } \\
\text { available to me through the College of Engineering. }\end{array}$ \\
$\begin{array}{l}\text { Member of College } \\
\text { I consider myself a member of the College of Engineering. } \\
\text { I am involved in extracurricular activities associated with the } \\
\text { College of Engineering }\end{array}$ \\
$\begin{array}{l}\text { Student Interactions with } \\
\text { Faculty }\end{array}$ & $\begin{array}{l}\text { I interact with professors outside of classroom time. } \\
\text { Developing relationships with faculty is important to me. }\end{array}$ \\
$\begin{array}{l}\text { Student Perceptions of } \\
\text { Faculty }\end{array}$ & $\begin{array}{l}\text { Professors are available to provide guidance to me. } \\
\text { Professors are available to help me with learning/understanding } \\
\text { course material outside of class. }\end{array}$ \\
$\begin{array}{l}\text { Study Habits with } \\
\text { Engineering Peers }\end{array}$ & $\begin{array}{l}\text { I sought a group of classmates to study with. } \\
\text { I sought help from my classmates with homework and studying. }\end{array}$ \\
$\begin{array}{l}\text { Relationships with } \\
\text { Engineering Peers }\end{array}$ & $\begin{array}{l}\text { I am friends with other engineering students. } \\
\text { I know upperclass students (sophomores, juniors or seniors) in } \\
\text { the College of Engineering. }\end{array}$ \\
$\begin{array}{l}\text { Comfortable Seeking Help } \\
\text { from Engineering Peers }\end{array}$ & $\begin{array}{l}\text { I feel comfortable seeking help with my classes from classmates. } \\
\text { I feel comfortable seeking help with my classes from upperclass } \\
\text { students. }\end{array}$ \\
\hline
\end{tabular}




\section{Data Analysis}

Participant responses were recoded with numerical values range from -2 for "strongly disagree" to 2 for "strongly agree". I reverse coded negatively worded items. As a result, there were no responses corresponding to a value of zero. I analyzed the data using a variety of statistical techniques in SPSS. To compare participants in the LLC with non-participants, I used independent sample t-tests and chi-square analyses. Further to explore the relationship between variables, I used regression modeling techniques.

\section{Results}

I have organized the results section under three subheadings that mirror the research questions examining the differences between participants and non-participants in an engineering LLC: (a) comparison of pre-college characteristics; (b) comparison of persistence-related attitudes and behaviors; and (c) comparison on direct measures of persistence.

\section{Pre-College Characteristics}

The first analysis of pre-college characteristics examined the two groups (LLC participants and non-participants) in terms of demographic data and academic performance. The two groups of participants were similar along most pre-college characteristics. As indicated in Table 3 below, independent sample t-tests revealed no significant differences between the groups in terms of pre-college academic performance measures.

Table 3: Comparison of Pre-College Academic Performance

\begin{tabular}{|c|c|c|c|c|c|c|c|c|c|c|}
\hline & $\mathbf{N}$ & Mean & $\begin{array}{l}\text { Std. } \\
\text { Dev. }\end{array}$ & $\begin{array}{c}\text { S.E. } \\
\text { Mean }\end{array}$ & $\mathbf{F}$ & Sig. & $\mathbf{T}$ & df & $\begin{array}{c}\text { Sig. } \\
\text { (2-tailed) }\end{array}$ & $\begin{array}{c}\text { Std. } \\
\text { Error } \\
\text { Diff. }\end{array}$ \\
\hline \multicolumn{11}{|c|}{ ACT Composite } \\
\hline LLC & 145 & 27.10 & 3.01 & .250 & 4.553 & .033 & .204 & 324 & .838 & .329 \\
\hline Non-LLC & 308 & 27.16 & 3.49 & .199 & & & & & & \\
\hline \multicolumn{11}{|c|}{ ACT Math } \\
\hline LLC & 145 & 28.37 & 3.09 & .257 & 9.833 & .002 & -.164 & 323 & .870 & .319 \\
\hline Non-LLC & 308 & 28.31 & 3.60 & .205 & & & & & & \\
\hline \multicolumn{11}{|c|}{ High School GPA } \\
\hline LLC & 145 & 3.72 & .303 & .025 & 4.138 & .043 & .497 & 361 & .620 & .035 \\
\hline Non-LLC & 264 & 3.70 & .388 & .024 & & & & & & \\
\hline
\end{tabular}

In contrast, there were significant differences in terms of the proportional distribution of gender and ethnicity in the two groups. A Chi-square test for independence indicated a 
significant association between gender and participation in the LLC, $\chi^{2}(1, \mathrm{n}=430)=5.873, \mathrm{p}=$ $.015, \phi=-1.08$. Women are overrepresented in the LLC in comparison to men. Another Chisquare test for independence indicated a significant association between ethnicity and participation in the LLC, $\chi^{2}(4, \mathrm{n}=409)=10.692, \mathrm{p}=.030, \phi=.147$. In terms of ethnicity, Asian and Black students tend to be overrepresented in the LLC, whereas international students are underrepresented. See Table 4 for a full summary of these data.

Table 4: Comparison of Basic Demographic Characteristics

\begin{tabular}{cccccccc}
\hline & Male & Female & White & Asian & International & Black & Other \\
\hline LLC & $80.4 \%$ & $19.6 \%$ & $84.4 \%$ & $8.8 \%$ & $2.0 \%$ & $4.1 \%$ & $0.7 \%$ \\
Non-LLC & $88.6 \%$ & $11.4 \%$ & $82.4 \%$ & $4.9 \%$ & $6.1 \%$ & $2.6 \%$ & $4.0 \%$ \\
\hline
\end{tabular}

Using the component factors identified through the PCA, I compared the two groups of participants on measures regarding students' expectations for college and their initial commitment to engineering. Student expectations were measured via the first administration of the survey at the beginning of the academic year (Time 0). Of the four theoretical components, participants in the LLC did not differ from students who chose not to participate in the LLC in terms of the initial measure of Commitment to Engineering and their expectations for Connection to Faculty.

However on the other two theoretical factors, Connection to the College and Connection to Peers, the two groups differed on all component factors. Participants in the LLC reported significantly higher expectations on the following component factors: (a) Member of College; (b) Supported by College; (c) Study Habits with Engineering Peers; (d) Relationships with Engineering Peers; and (d) Comfortable Seeking Help from Engineering Peers. Complete results from the independent sample t-tests are reported in Table 5.

Table 5: Comparison of Expectations for College and Studying Engineering

\begin{tabular}{|c|c|c|c|c|c|c|c|c|c|c|}
\hline & $\mathrm{N}$ & Mean & $\begin{array}{l}\text { Std. } \\
\text { Dev. }\end{array}$ & $\begin{array}{l}\text { S.E. } \\
\text { Mean }\end{array}$ & $\mathrm{F}$ & Sig. & $\mathrm{T}$ & df & $\begin{array}{c}\text { Sig. } \\
\text { (2-tailed) }\end{array}$ & $\begin{array}{c}\text { Std. Error } \\
\text { Diff. }\end{array}$ \\
\hline \multicolumn{11}{|c|}{ Commitment to Engineering } \\
\hline LLC & 122 & 1.02 & .861 & .078 & .003 & .955 & 1.05 & 369 & .294 & .094 \\
\hline Non-LLC & 249 & .93 & .848 & .054 & & & & & & \\
\hline \multicolumn{11}{|c|}{ Member of College } \\
\hline LLC & 123 & 0.27 & .890 & .080 & .206 & .650 & 2.73 & 372 & $.007 *$ & .100 \\
\hline Non-LLC & 251 & 0.00 & .914 & .058 & & & & & & \\
\hline \multicolumn{11}{|c|}{ Supported by College } \\
\hline LLC & 121 & 1.47 & .533 & .048 & .045 & .832 & 1.99 & 371 & $.048^{*}$ & .063 \\
\hline Non-LLC & 252 & 1.34 & .580 & . 037 & & & & & & \\
\hline
\end{tabular}




\begin{tabular}{|c|c|c|c|c|c|c|c|c|c|c|}
\hline \multicolumn{11}{|c|}{ Student Perceptions of Faculty } \\
\hline LLC & 123 & 1.39 & .654 & .059 & 1.421 & .234 & 1.32 & 376 & .187 & .080 \\
\hline Non-LLC & 255 & 1.28 & .762 & .048 & & & & & & \\
\hline \multicolumn{11}{|c|}{ Student Interactions with Faculty } \\
\hline LLC & 122 & 0.74 & 836 & .076 & 214 & .644 & .569 & 373 & .570 & .090 \\
\hline Non-LLC & 253 & 0.68 & .807 & .051 & & & & & & \\
\hline \multicolumn{11}{|c|}{ Comfortable Seeking Help from Engineering Peers } \\
\hline LLC & 121 & 1.18 & .866 & .078 & 8.276 & .004 & 3.57 & 279 & $.000 *$ & 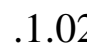 \\
\hline Non-LLC & 254 & 0.82 & 1.04 & .065 & & & & & & \\
\hline \multicolumn{11}{|c|}{ Relationships with Engineering Peers } \\
\hline LLC & 123 & 0.72 & .801 & .072 & 11.71 & .001 & 5.95 & 296 & $.000 *$ & .096 \\
\hline Non-LLC & 254 & 0.15 & 1.00 & .063 & & & & & & \\
\hline \multicolumn{11}{|c|}{ Study Habits with Engineering Peers } \\
\hline LLC & 121 & 1.10 & .864 & .079 & 1.364 & .244 & 2.36 & 375 & $.019 *$ & .101 \\
\hline Non-LLC & 256 & 0.86 & .934 & .058 & & & & & & \\
\hline
\end{tabular}

\section{Reported Attitudes and Behaviors}

In this section, I report the comparison of attitudes and behaviors of engineering students on the component factors related to persistence. To identify the potential effect of participating in the LLC, I examined participants' responses at the end of year administration (Time 2). At that time, participants were reporting their current attitude and reflecting on their behaviors over the past semester.

At Time 2, there were significant differences between the two groups on component factors measuring students' Connection to the College and Connection to Peers. Specifically, participants in the LLC reported stronger agreement to statements of the following component factors: (a) Member of the College; (b) Comfortable Seeking Help from Engineering Peers; (c) Relationships with Engineering Peers; and (d) Study Habits with Engineering Peers. All of the results from these $\mathrm{t}$-tests are reported in Table 6.

Table 6: Comparison of Attitudes and Behaviors at the End of the Academic Year

\begin{tabular}{lcccccccccc}
\hline \multicolumn{1}{c}{ N } & Mean & $\begin{array}{c}\text { Std. } \\
\text { Dev. }\end{array}$ & $\begin{array}{c}\text { S.E. } \\
\text { Mean }\end{array}$ & F & Sig. & T & df & $\begin{array}{c}\text { Sig. } \\
\text { (2-tailed) }\end{array}$ & $\begin{array}{c}\text { Std. Error } \\
\text { Diff. }\end{array}$ \\
\hline $\begin{array}{l}\text { Commitment to Engineering } \\
\text { LLC }\end{array} 103$ & 0.75 & 1.01 & .099 & .323 & .570 & 1.18 & 291 & .240 & .125 \\
Non-LLC & 190 & 0.61 & 1.03 & .074 & & & & & & \\
Member of College & & & & & & & & \\
$\quad$ LLC & 105 & -0.03 & 1.04 & .101 & .002 & .963 & 2.62 & 297 & $.009 *$ & .123 \\
Non-LLC & 194 & -0.35 & 1.00 & .072 & & & & & &
\end{tabular}




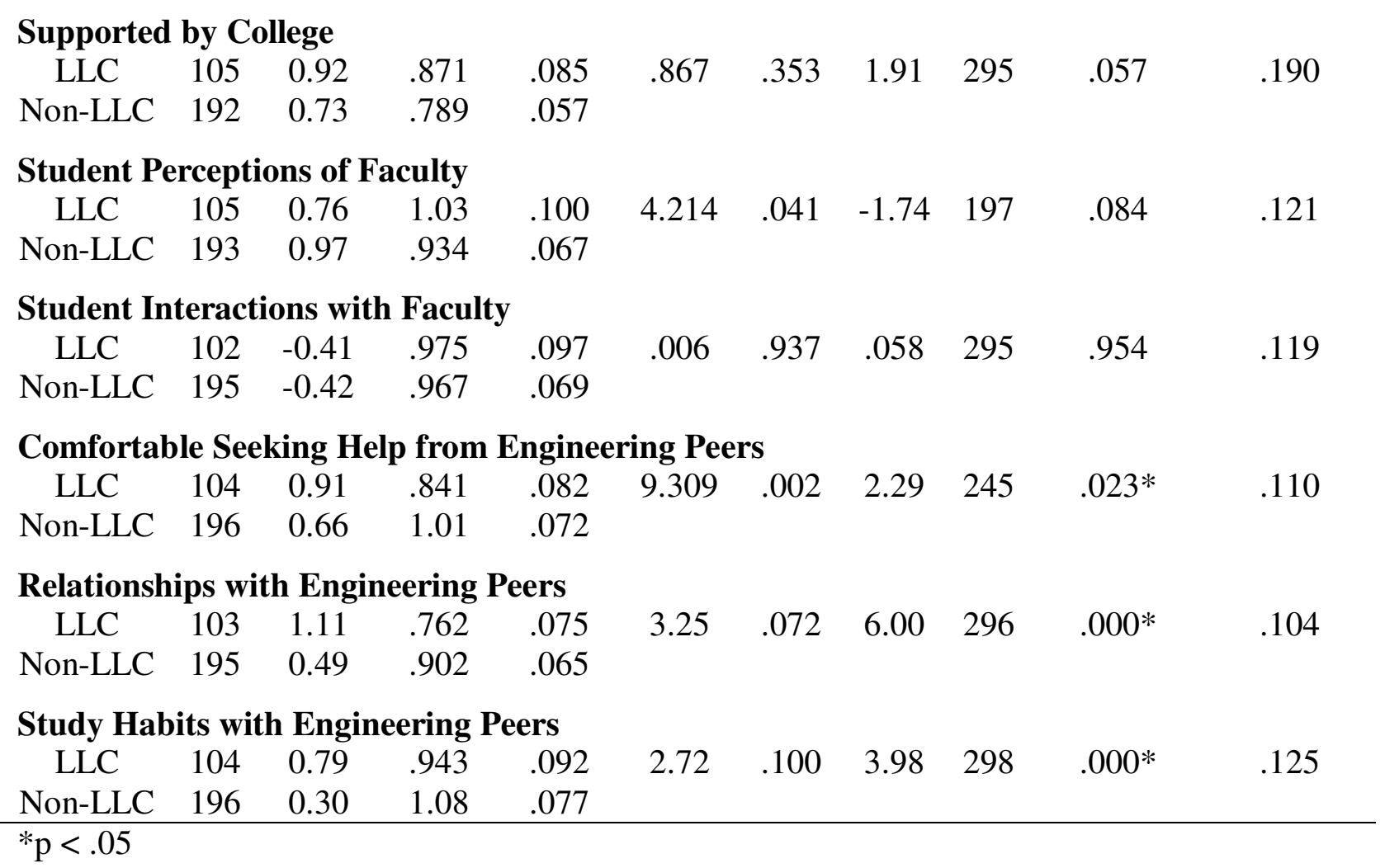

In attempt to better understand these differences and the unique effect of participating in the LLC, I conducted a linear regression model including measures of pre-college academic achievement (ACT composite score), gender and ethnicity. For each model, I conducted preliminary tests to ensure no violations of regression modeling assumptions in terms of multicollinearity, normality, linearity, homoscedasticity, and independence of residuals. On three component factors, participation in the LLC had a significant predictive effect: (a) Member of College; (b) Relationships with Engineering Peers; and (c) Study Habits with Engineering Peers. The magnitude of the predictive power was modest in each case, but significant.

For the Member of College component factor, the model explained 5\% of the variance, $\mathrm{F}$ $(4,274)=3.768, p=.006$. The influence of participation in the LLC was statistically significant ( $\beta=.147, p=.014)$. For the Relationships with Engineering Peers component factor, the model explained $11 \%$ of the variance, $\mathrm{F}(4,271)=8.440, \mathrm{p}<.001$. The influence of participation in the LLC was statistically significant $(\beta=.325, \mathrm{p}<.001)$. Finally for the Study Habits with Engineering Peers component factor, the model explained $7 \%$ of the variance, $F(4,273)=5.049$, $\mathrm{p}=.001$. The influence of participation in the LLC was statistically significant $(\beta=.217, \mathrm{p}<$ $.001)$.

\section{Measures of Persistence}

For this study, there are two direct measures of persistence. First, participants responded to a statement rating their likelihood to continue in an engineering major at Time 2. Using an 
independent sample t-test, there was no significant difference between students participating in the LLC and students not participating in the LLC, $t(299)=-.130, p=0.897$.

Second, I examined the prevalence of disciplinary leavers in each subgroup and the characteristics of those leavers. Overall $21 \%$ of pre-engineering students in the first-year introductory design sequence were not registered in an engineering college major at the start of their second year. A Chi-square test for independence indicates a significant association between not participating in the LLC and departure from engineering $\chi^{2}(1, \mathrm{n}=499)=5.115 \mathrm{p}=.024, \phi$ $=.101$. In the sample, LLC students are retained within engineering disproportionately in comparison to students not participating in the LLC. Only $14.9 \%$ of LLC students were enrolled in a non-engineering major in fall 2010 compared to $23.9 \%$ of the other first-year students.

In addition to these direct comparisons, I modeled the relationship between the various composite factors and pre-college characteristics, and these persistence measures. For the rating of students' likelihood to persist, the linear regression model explained $45 \%$ of the variance $\mathrm{F}$ $(12,263)=19.422, \mathrm{p}<.000$, after ensuring the appropriate assumptions for regression were not violated. The only significantly predictive component factors were: (a) Commitment to Engineering $(\beta=.618, \mathrm{p}<.001)$; and $(\mathrm{b})$ Relationships with Engineering Peers $(\beta=.136, \mathrm{p}=$ .013). As shown previously, there is a relationship between participating in a LLC and the Relationships with Engineering Peers component factor.

Finally, I modeled the choice of major at the start of the students' sophomore year with the composite factors and pre-college characteristics. The model contained 12 independent variables (composite factors related to persistent, gender, ethnicity and pre-college academic achievement). The full model was statistically significant $\chi^{2}(14, \mathrm{n}=272)=60.549 \mathrm{p}<.001$ indicating that the model was able to distinguish between respondents who remained in the engineering major and those who did not. The model explained between 20-39\% of the variance in choice of major at the start of sophomore year. Only two of the variables made a unique statistically significant contribution: (a) pre-college academic achievement; and (b) Commitment to Engineering. Neither of these variables relate to membership in the LLC based on the aforementioned analyses.

\section{Discussion}

The results of this paper enhance our understanding of the use of LLCs and their relationship to measures of persistence and likelihood to persist. Although the findings advance our understanding in this area, it is important to keep in mind that these results are part of study located at one institution in a single year of data collection. As a result, the findings should not be overgeneralized. Further, because the study occurred in the students' first year, we should expect to see minimal effects on many of these measures. The participants are just beginning their college experience and those in the LLC will have only been in residence for a short time. Finally the results should be interpreted cautiously given the selection bias associated with participating in the LLC. As demonstrated by the expectations data, these two groups of students differ in some significant ways. Although analyzing the data using regression modeling attempts to remove some of this bias, the potential for selection bias remains a concern, especially for the more basic analyses. 
First, although there are no differences in terms of academic preparation, it appears that LLCs are more effective at attracting Asian and African-American students than they are at attracting international students. Furthermore, female students tend to participate in LLCs in disproportionate numbers. These findings suggest that LLCs could potentially serve as an important support mechanism for two populations (African-American students and women) that are underrepresented in engineering.

In addition, the results of the study indicate that those students who participate in LLCs have slightly different expectations for their time in college. The differences between participants and non-participants in LLCs relate to their relationship to the college of engineering and their connection to other engineering students. Students who participate in LLCs tend to expect to be more connected to the college of engineering and are more likely to view themselves as a member of the college. Furthermore, LLC residents expect to have more friends who are engineering students, to study more often with other engineering students, and to be more comfortable seeking help from other engineering students.

In terms of the influence of LLCs on disciplinary retention, and related attitudes and behaviors the results are mixed. The most direct effect of participation in LLC is on the theoretical factors of Connection to the College and Connection to Peers. The relationship was strongest for the component factors of (a) Member of College, (b) Relationships with Engineering Peers, and (c) Study Habits with Engineering Peers that was confirmed by regression models. These findings are consistent with previous research on LLCs. Although the effect is not direct, this evidence suggests that LLCs positively contribute to students' sense of belonging. Further these findings are consistent with previous research on LLCs in terms of promotion of student engagement and involvement including peer relationships. ${ }^{22,23,24}$

Interestingly, there are no significant differences between participants and nonparticipants in the LLC on all component factors of Connection to Faculty. This finding is surprising because it contradicts previous work on the impact of LLCs. ${ }^{25,26}$ There a number of potential explanations for this lack of impact. For example, there may be a specific cultural difference in engineering that may not lend itself to a differential student-faculty experience for students in a LLC. Another possible explanation is that the LLC in this study may not be structured in a way that promotes increased student-faculty interactions beyond the experiences available to all students.

At this stage of measurement, there is minimal evidence for the LLC influencing disciplinary retention. There is no direct relationship between participating in the LLC and persistence. Although students participating in the LLC are more likely to remain in an engineering major at the start of the sophomore year, this relationship was not confirmed by the results of the regression model. Thus, although promising, it is inappropriate to attribute an increase in disciplinary retention to participation in the LLC.

Despite the lack of clear evidence of the LLC impacting disciplinary retention, the results of the study identified some potential indirect impacts on retention. One promising finding relates to the influence of LLCs on students' Connection to Engineering Peers. Participants in the 
LLC reported higher scores on all peer-related component factors. One of the peer component factors (Relationships with Engineering Peers) was significantly predictive of likelihood to remain in engineering. Thus there is evidence for an indirect link between participation in a LLC and disciplinary retention.

Overall the findings of this study are promising. As an early stage measure of the impact of LLCs on disciplinary retention, there were no clear direct effects. However, on a number of related measures, LLCs appear to positively impacting students' engineering experience by increasing both their connection to the engineering college, and their connection to other engineering students. Given the theoretical basis for studying these related factors and previous research linking these factors to persistence, the findings of this study suggest potential for LLCs to be a worthwhile intervention in promoting disciplinary retention; however further research is necessary to establish this connection.

In addition to replicating and expanding the present study, the findings suggest many opportunities for continued work in the area. From a data analysis standpoint, I plan to pursue more sophisticated techniques of controlling for factors and covariance to clarify the strength of the relationships identified in this study. Further this longitudinal data set provides many options for potential modeling including fixed effects regression which may identify other relationships between variables that are currently muted in the aggregate. Finally this study suggests a number of potential research projects to further examine the impact of LLCs on retention and related outcomes in engineering education. Some potential projects include (a) measuring impact on students as they near graduation to gain more reliable retention data, (b) identifying what elements of the LLC make an impact on students, and (c) studying the effect of LLCs on learning outcomes as well as the issue of retention within the discipline.

\section{Acknowledgements}

This material is based upon work supported by the National Science Foundation under award 0757020 (DUE). Any opinions, findings and conclusions or recommendations expressed in this material are those of the author(s) and do not necessarily reflect the views of the National Science Foundation (NSF).

\section{References}

${ }^{1}$ Committee on Prospering in the Global Economy of the 21st Century. (2007). Rising Above the Gathering Storm: Energizing and Employing America for a Brighter Economic Future. Washington, DC: National Academies Press.

${ }^{2}$ National Science Board. (2008). Science and Engineering Indicators 2008, Volume 1. Washington, DC: National Science Foundation. Retrieved from: http://www.nsf.gov/statistiscs/seind08/

${ }^{3}$ Seymour, E. (2002). Tracking the Processes of Change in US Undergraduate Education in Science, Mathematics, Engineering, and Technology. Science Education. 85(6), 79-105.

${ }^{4} \mathrm{NSB},(2008)$.

${ }^{5}$ Seymour, E. \& Hewitt, N. M. (1997). Talking about leaving: Why undergraduates leave the sciences. Boulder, CO: Westview Press 
${ }^{6}$ Johnson, M., \& Smith, M. (2008). Designing Appropriate Scaffolding for Student Science Projects. Journal of College Science Teaching. 38(2), 24-29.

${ }^{7}$ Sheppard, S. D., Macatangay, K., Colby, A. \& Sullivan, W. M. (2009). Educating engineers: Designing for the future of the field. San Francisco: Jossey-Bass.

${ }^{8}$ Gaff, J. G. (1970). The cluster college. San Francisco: Jossey-Bass.

${ }^{9}$ Inkelas, K. K., Zeller, W. J., Murphy, R. K. \& Hummel, M. L. (2006). Learning moves home. About Campus, $10(6), 10-16$.

${ }^{10}$ Gaff, (1970).

${ }^{11}$ Gamson, Z. F. (2000). The origins of contemporary learning communities: Residential colleges, experimental colleges, and living-learning communities. In D. DeZure (ed.), Learning from change: Landmarks in teaching and learning from Change magazine 1969-1999. Sterling, VA: Stylus Publishing.

${ }^{12}$ Inkelas et al., (2006)

${ }^{13}$ Veenstra, C.P., Dey, E.L., \& Herrin, G.D. (2009, Winter). A model for freshman engineering retention. Advances in Engineering Education 1(3), 1-31

${ }^{14}$ Micomonaco, J. P. \& Sticklen, J. (2010). Toward a better understanding of academic and social integration: A qualitative study of factors related to persistence in engineering. Proceedings of the American Association of Engineering Education (ASEE) Annual Conference, Louisville, KY.

${ }^{15}$ Tinto, V. (1993). 2nd Edition. Leaving college: Rethinking the causes and cures of student attrition. Chicago: The University of Chicago Press

${ }^{16}$ Tinto, (1993)

${ }^{17}$ Veenstra et al., (2009)

${ }^{18}$ Ibid

${ }^{19}$ Micomonaco \& Sticklen, (2010)

${ }^{20}$ Veenstra et al., (2009)

${ }^{21}$ DeCoster, J. (1998). Overview of Factor Analysis. Retrieved March 7, 2011 from http://www.stathelp.com/notes.html.

22 Inkelas, K. K. (1999). The tide on which all boats rise: The effects of living-learning participation on undergraduate outcomes at the University of Michigan. Ann Arbor, MI: University Housing.

${ }^{23}$ Inkelas, K. K., \& Weisman, J. L. (2003). Different by Design: An Examination of Student Outcomes among Participants in Three Types of Living-Learning Programs. Journal of College Student Development. 44(3), 335-68.

${ }^{24}$ Pike, G. R. (1999). The effects of residential learning communities and traditional residential living arrangements on educational gains during the first year of college. Journal of College Student Development, 40(3), 269284.

${ }^{25}$ Inkelas \& Weisman (2003)

${ }^{26}$ Pike, (1999) 